\title{
PENGARUH TERAPI RELAKSASI AUDIO MUROTTAL AL-QUR'AN TERHADAP PERUBAHAN TINGKAT KECEMASAN PADA PASIEN YANG DI RAWAT DI RUANGAN ICU RUMAH SAKIT AMINAH
}

\author{
Yeni Sulistyowati, Muhammad Taufik Daniel Hasibuan \\ Program Studi Ilmu Keperawatan, STIKes Murni Teguh \\ E-mail : yenisulis.kep19@gmail.com; aniel.jibril@gmail.com
}

\begin{abstract}
Murottal therapy is one type of music therapy that has a positive influence on listeners, where when someone listens to murottal therapy it will provide stimulation to the eardrum which will then be transmitted through the auditory nerve to the auditory cortex in the brain so that there will be a decrease in cortisol which can cause a relaxed feeling. and comfortable. This study aims to determine the effect of audio murottal al-qur'an relaxation therapy on the anxiety level of patients treated in the ICU. The research method used is quantitative research with quasi-experimental design and one group pretest posttest design and statistical test using Wicolxon test. The population studied were patients who were treated in the ICU room of Aminah Hospital and the sample studied was 38 people who were taken by using purposive sampling technique. The results of the study using the Wicolxon statistical test, obtained $\mathrm{p}$ value $=0.000(\mathrm{p}<=0.05)$, it can be concluded that there is an effect of anxiety levels before and after giving murottal Al-Qu'an therapy to decrease anxiety levels. From the results of this study, it is hoped that all health workers in the ICU will continue to improve their performance and routinely provide Ar-Rahman letter therapy to patients who experience anxiety while being treated in the ICU.
\end{abstract}

Keywords: Audio Relaxation, Murottal Al-Qur'an, Anxiety

\begin{abstract}
Abstrak
Terapi murottal merupakan salah satu jenis terapi musik yang memiliki pengaruh positif pada pendengar, dimana saat seseorang mendengarkan terapi murottal maka akan memberikan rangsangan pada gendang telinga yang kemudian akan diteruskan melalui saraf pendengaran ke korteks pendengaran di otak sehingga akan terjadi penurunan kortisol yang dapat menimbulkan perasaan santai dan nyaman. Penelitian ini bertujuan untuk mengetahui pengaruh terapi relaksasi audio murottal al-qur'an terhadap tingkat kecemaasan pasien yang di rawat di ruangan ICU. Metode penelitian yang digunakan adalah penelitian kuantitatif dengan desain eksperimen semu dan rancangan one group pretest posttest serta uji statistik menggunakan Uji Wicolxon. Populasi yang diteliti adalah pasien yang di rawat di ruangan ICU Rumah Sakit Aminah dan sampel yang diteliti sebanyak 38 orang yang diambil dengan cara menggunakan teknik purposive sampling. Hasil penelitian dengan menggunakan uji statistik wicolxon di dapatkan $\mathrm{p}$ value $=0.000$ $(\mathrm{p}<\alpha=0.05)$, maka dapat disimpulkan ada pengaruh tingkat kecemasan sebelum dan sesudah pemberikan terapi murottal Al-Qu'an terhadap penurunan tingkat kecemasan. Dari hasil penelitian ini diharapkan kepada semua petugas kesehatan yang ada di ruang ICU agar tetap meningkatkan kinerja dan rutin memberikan terapi surat Ar-Rahman kepada pasien yang mengalami kecemasan saat di rawat di ruang ICU.
\end{abstract}

Kata kunci: Relaksasi Audio, Murottal Al-Qur'an, Kecemasan 


\section{PENDAHULUAN}

Kecemasan adalah perasaan tidak santai karena rasa takut yang disertai suatu respon (penyebab tidak spesifik atau tidak diketahui oleh individu) [1]. Setiap orang pernah mengalami pengalaman cemas. Gangguan cemas ini biasanya ditandai dengan perasaan bingung, tidak senang, rasa takut yang tidak jelas, diretai dengan gejala otonom seperti sakit kepala, jangtung berdebar, berkeringat, perasaan tertekan di dada, tidak nyaman didaerah perut, keresahan, yang ditandakan dengan ketidakmampuan untuk duduk atau berdiri dalam jangka waktu yang lama [2].

Sebesar $29 \%$ orang dewasa di Amerika, sepanjang hidupnya mengalami gangguan kecemasan, dan 18\% dalam waktu 12 bulan. Orang yang mengalami gangguan kecemasan akan mengganggu aktifitas sehari-harinya dan pengobatan pertama biasanya dimulai setelah 10 tahun mengalami gangguan ini. Berdasarkan studi Comorbidity Nasional mendapatkan bahwa 1 diantara 4 orang mengalami gangguan kecemasan dengan angka prevelen $17.7 \%$ dari populasi. Jenis kelamin perempuan lebih besar berisiko mengalami gangguan kecemasan 30.5\% sepanjang hidupnya dibandingkan laki-laki berisiko sekitar $19.2 \%$. Prevelensi gangguan kecemasan akan menurun dengan meningkatnya status ekonomi [2].

Pasien yang di rawat di ruang ICU (Intensive Care Unit) memiliki nilai kematian dan kesakitan yang tinggi. Pasien kritis sangat erat kaitannya dengan perawatan secara intensif serta monitoring penilaian terhadap setiap tindakan yang dilakukan kepada pasien dan membutuhkan pencatatan medis secara terus-menerus dan berkesinambungan. Pasien yang di rawat di ICU tentunya akan mengalami masalah psikis, masalah psikis dapat terjadi berupa gangguan kecemasan, depresi hingga psikosis. Prevelensi tingkat kecemasan pasien yang di rawat di ICU adalah kecemasan ringan $15 \%$, sedang $72,5 \%$ dan berat $12,5 \%$ [3].

Pendekatan psikologis di bidang kesehatan untuk mengurangi kecemasan yang dialami pasien dengan penyakit kronis telah dikembangkan. Salah satunya dengan pendekatan yang memperhatikan dimensi spiritual. Pendekatan spiritual dengan pendekatan psikoreligius dipandang sebagai alternatif yang dianggap penting dan efektif untuk meningkatkan rasa percaya diri, optimisme, dan kekebalan pasien. Pendekatan psikoreligius dengan menggunakan objek-objek yang dianggap sakral oleh individu menunjukkan hasil yang signifikan untuk mengurangi stres [4].

Mendengarkan pengajian Al-Qur'an sebagai kitab suci umat Islam memiliki pengaruh pada diri sendiri, terutama dalam memberikan ketenangan dan mengurangi tingkat cemas. Seperti pada konferensi tahunan XVII American Medical Association, kawasan Missuori dipaparkan oleh Ahmad Al-Kahdi tentang hasil penelitiannya yang bertema pengaruh Alquran terhadap manusia dari perspektif fisiologis dan psikologis. Hasil penelitian ini menunjukkan bahwa mendengarkan ayat suci Al-Qur'an memiliki pengaruh yang signifikan dalam mengurangi ketegangan syaraf reflektif dan hasil tersebut dicatat dan diukur secara kuantitatif dan kualitatif dengan alat berbasis komputer.

Hasil penelitian menunjukkan
manfaat Murottal Al-Qur'an dalam menurunkan tingkat kecemasan pasien hemodialisis di rumah sakit. PKU Muhammadiyah Surakarta [5]. Membaca AlQur'an dapat memberikan efek relaksasi, menyebabkan pembuluh darah dan detak jantung menurun. Murottal Al-Qur'an jika diputar kepada orang atau pasien akan memunculkan gelombang suara dan mendorong otak untuk memproduksi zat kimia yang disebut neuropeptida yang mempengaruhi reseptor di dalam tubuh, sehingga tubuh terasa nyaman [6].

\section{METODE PENELITIAN}

Desain penelitian dalam penelitian ini adalah Quasy Eksperimen dengan menggunakan desain One Group PretestPostest. Dalam rancangan ini, tidak ada kelompok pembanding (kontrol) tetapi paling 
tidak sudah dilakukan observasi pertama (pretes) yang memungkinkan peneliti dapat menguji perubahan yang terjadi setelah adanya eksperimen. Penelitian ini bertujuan untuk melihat pengaruh terapi relaksasi audio: Murottal Al Qur'an surah Ar-Rahman (QS: 55, 78 ayat) yang dilantunkan oleh Abi Tulkhah dengan durasi 13 menit 55 detik, menggunakan handphone dengan Aplikasi Murottal Offline 30 juz yang disambungkan dengan earphone atau headset. Dengan 2 periode pada hari pertama (pre test) dan pada hari kedua (post test), kemudian di lakukan penilaian tingkat kecemasan. Penelitian ini dilakukan di Rumah Sakit Aminah, tepatnya di Ruang Intensive Care Unit (ICU) Non Covid dan Intensive Care Unit (ICU) Covid pada bulan Maret 2021 sampai dengan bulan April 2021.

\section{HASIL PENELITIAN}

\section{Analisa Univariat}

Hasil tingkat kecemasan sebelum dilakukan intervensi (pre test) terapi relaksasi audio murottal al-quran yaitu :

Tabel 1. Distribusi Frekuensi Tingkat Kecemasan Sebelum Dilakukan Intervensi

\begin{tabular}{|c|c|c|}
\hline Tingkat Kecemasan & $\mathbf{F}$ & $\%$ \\
\hline Ringan & 10 & 26 \\
\hline Sedang & 28 & 74 \\
\hline Total & 38 & 100 \\
\hline
\end{tabular}

Dari tabel diatas didapatkan hasil tingkat kecemasan sebelum dilakukan intervensi yaitu ringan (26\%), dan sedang $(74 \%)$.

Hasil tingkat kecemasan sesudah dilakukan intervensi (post test) terapi relaksasi audio murottal al-quran yaitu :

Tabel 2. Distribusi Frekuensi Tingkat Kecemasan Sesudah Dilakukan Intervensi

\begin{tabular}{|c|c|c|}
\hline Tingkat Kecemasan & $\mathbf{F}$ & $\%$ \\
\hline Ringan & 16 & 42 \\
\hline Sedang & 22 & 58 \\
\hline
\end{tabular}

Dari tabel diatas didapatkan hasil tingkat kecemasan sesudah dilakukan intervensi yaitu ringan (42\%), dan sedang $(58 \%)$.

\section{Analisa Bivariat}

Hasil Uji Wilcoxon untuk melihat pengaruh tingkat kecemasan pada sebelum dan sesudah diberikan intervensi audio murottal al-quran yaitu :

Tabel 3. Pengaruh Terapi Relaksasi Audio Murottal Al-Quran Terhadap Tingkat Kecemasan yaitu:

\begin{tabular}{lccc}
\hline Terapi & \multicolumn{2}{c}{ Tingkat Kecemasan } & \multirow{2}{*}{$\boldsymbol{p}$} \\
\cline { 2 - 3 } Murottal & Ringan & Sedang & \\
\hline Pre Tes & 10 & 28 & \multirow{2}{*}{000} \\
\hline Post Tes & 16 & 22 & \\
\hline
\end{tabular}

Hasil Uji Wilcoxon didapatkan nilai signifikansi ( $\mathrm{p}$ value $=0,000$ ) dimana hal ini berarti $\mathrm{p}$ value $<0,05$ sehingga $\mathrm{H} 1$ diterima artinya ada pengaruh tingkat kecemasan sebelum dan sesudah pemberian terapi murottal Al-Qu'an terhadap penurunan tingkat kecemasan pada pasien yang dirawat di ruang ICU Rumah Sakit Aminah.

\section{PEMBAHASAN}

Dari hasil uji statistik Wilcoxon untuk melihat pengaruh audio murottal alquran terhadap tingkat kecemasan didapatkan nilai $\mathrm{p}$-value $=0,000$. Hal ini berarti ada pengaruh penurunan tingkat kecemasan sebelum dan sesudah pemberikan terapi murottal Al-Qu'an pada pasien yang dirawat di ruang ICU Rumah Sakit Aminah.

Mayoritas responden mengalami penuruan tingkat kecemasan setelah dilakukan intervensi (terapi murottal) dan ada beberapa responden yang tidak mengalami penurunan tingkat kecemasan setelah dilakukan intervensi (terapi murottal). Hal ini disebabkan oleh kurang konsentrasi dalam pelaksanaan terapi murottal Al-Qur'an dan faktor-faktor lain yaitu lingkungan atau suara alat-alat yang ada di Ruang ICU menjadikan responden tidak bisa konsentrasi. Hal ini sesuai dengan penelitian yang dilakukan sebelumnya bahwa Murottal Al-Qur'an bermanfaat dalam menurunkan tingkat kecemasan pasien hemodialisis di rumah sakit [5].

Murottal merupakan salah satu musik yang memiliki pengaruh positif bagi pendengarnya. Mendengarkan ayat AlQur'an yang dibacakan dengan tartil dan 
benar akan membawa ketenangan pikiran. Pembacaan Al-Qur'an secara fisik mengandung unsur suara manusia, sedangkan suara manusia adalah alat penyembuhan yang luar biasa dan paling mudah dijangkau. Suara dapat menurunkan hormon cemas, mengaktifkan hormon endorphin alami, meningkatkan perasaan rileks, dan mengalihkan perhatian dari rasa takut, cemas dan tegang, meningkatkan sistem kimiawi tubuh sehingga menurunkan tekanan darah dan memperlambat pernapasan, detak jantung, denyut nadi, dan aktivitas gelombang otak. Hal ini menunjukkan bahwa membaca AlQur'an dapat dijadikan pengobatan pelengkap karena dapat meningkatkan perasaan rileks [7].

\section{KESIMPULAN}

Hasil penelitian menunjukkan bahwa terapi murottal Al-Qu'an dapat menurunkan kecemasan pada pasien yang dirawat di ruang ICU RS Aminah. Uji Wilcoxon Signed Rank Test pada tingkat kecemasan pre dan post test didapatkan $\mathrm{p}$-value $=<0,05$

\section{SARAN}

1. Bagi Instansi Rumah Sakit

Sebagai masukkan dalam meningkatkan kualitas pelayanan khususnya intervensi keperawatan yang berorientasi pada keperawatan nonfarmakalogi di ruang ICU, berupa Terapi Relaksasi Audio: Murotal Al-Qur'an (Surat Ar-Rahman) dalam menurunkan tingkat cemas pasien dan diharapkan bisa diterapkan disetiap ruangan perawatan lainnya.

2. Bagi Instansi Pendidikan

Penelitian ini dapat dijadikan sebagai tambahan kepustakaan untuk mengembangkan ilmu pengetahuan dan kesehatan.

3. Bagi Perawat

Dari hasil penelitian ini bisa dijadikan implementasi untuk tindakan keperawatan khususnya tindakan mandiri untuk mengurangi tingkat kecemasan pasien yang dirawat di Ruang ICU atau Ruang Rawat Inap di RS Aminah. Hal ini tentunya dapat membuat pelayanan di RS
Aminah menjadi lebih maksimal dan sebagai perawat bisa lebih mengutamakan sikap caring disamping dengan patien safety. Bila kecemasan pasien sudah teratasi maka akan berpengaruh pada hemodinamik dan kondisi psikologis pasien, menjadikan jumlah hari rawat atau kos pasien di ruang ICU bisa menurun.

\section{REFERENSI}

1. Fitryasari, Y, R., \& Nihayati, H, E. (2015). Buku Ajar Keperawatan Kesehatan Jiwa. Jakarta: Salemba Medika.

2. Sadock, B, J., Sadock, V, A., \& Ruiz, P. (2015). Synopsis of psychiatry behavioral sciences/ clinical psychiatry. chapter 9 anxiety disorder. eleventh edition.Wolters Kluwer: Philadelphia

3. Rosida, L., Imardiani, I., \& Wahyudi, J. T. (2019). Pengaruh terapi relaksasi autogenik terhadap kecemasan pasien di ruang intensive care unit rumah sakit pusri Palembang. Indonesian Journal for Health Sciences, 3(2), 52. https://doi.org/10.24269/ijhs.v3i2.1842

4. Miller, L, M., Gall, T, L., \& Corbeil, L. (2011). The Experience of Prayer With a Sacred Object Within the Context of Significant Life Stress. Journal of Spirituality in Mental Health, 13, 247271. doi: 10. 1080.

5. Zahrofi, D, N. (2013). Pengaruh pemberian terapi murotal Al-Qur'an terhadap tingkat kecemasan pada pasien hemodialisa di RS PKU Muhammadiyah Surakarta. Skripsi. Universitas Muhammadiyah Surakarta.

6. Handayani, D., et al. (2014). Sistem skor acute physiology and chronic health evaluation (apache) II sebagai prediksi mortalitas pasien rawat instalasi perawatan intensif. Fakultas Kedokteran Universitas Indonesia.

7. Eskandari, N., et.al (2012). Qur'an recitation: short-term effect and related factors in preterm newborns. Research journal of medical sciencnces. 